\title{
ANALISIS PENGARUH BEBERAPA DOSIS PUPUK BOKASHI KOTORAN AYAM TERHADAP PERTUMBUHAN DAN PRODUKSI TIGA VARIETAS TOMAT (Solanum lycopersicum L.) DI DESA AIRMADIDI
}

\author{
Marthinus Marcus Sahetapy \\ Jantje Pongoh \\ Wenny Tilaar
}

\begin{abstract}
Objectives of the study were to determine The effects of analysis the live stock bokashi fertilizer in several dosage to respons on growth and yield the three varieties of tomatos (Solanum lycopersicum L.) in Airmadidi Village. This study aims to determine the varieties of tomatos that can provide the best respons to growth and yield to effects the live stock bokashi fertilizer in several dosage.The research was conducted in October 2016 and February 2017 in the field experiment of Klabat University Airmadidi North Minahasa Regency. The research was conducted in factorial experiment wich arranged in a Randomized block design (RBD) with the each combination treatment was replicated three times. The factorial is consists of 2 factors : The first factor is the variety which consists of three levels, namely varieties (Tantyna F1), varieties (Tombatu F1) and varieties (Betavila F1). The second factor are the several dosage of live stock bokashi fertilizer which consists of four levels e.i, 10 ton in ha, 15 ton in ha, 20 ton in ha and 25 ton in haEach plot of treatment consist of 12 plan and between of the plan have the 5 exampel plan. Data were analyzed by analysis of variance at $5 \%$ significance level and to know the difference between treatments using test BNJ $5 \%$. The result showed that the best plant growth and production was found at the combination of Betavila varieties and bokashi fertilizer 15 ton in ha. The best plant growth and production of varieties was found at the Betavila varieties. The best plant growth and production of dosage the live stock bokashi fertilizer was found at dosage 15 ton in ha.
\end{abstract}

Keywords: variety, live stock bokashi fertilizer, tomato. Airmadidi Village, North Minahasa Regency.

\section{ABSTRAK}

Tujuan dari pada penelitian ini untuk mengetahui respon pertumbuhan dan hasil tiga varietas tanaman tomat ((Solanum lycopersicum L.) terhadap penggunaan beberapa dosis pupuk bokashi kotoran ayam. Penelitian ini dilaksanakan pada bulan Oktober 2016 sampai dengan Februari 2017 di kebun percobaan Universitas Klabat Airmadidi Kabupaten Minahasa Utara. Penelitian ini dilaksanakan dalam percobaan faktorial yang dirancang secara acak kelompok (RAK) dengan masing-masing kombinasi perlakuan diulang tiga kali. Faktorial terdiri dari 2 faktor factor pertama adalah varietas tomat (V) yang terdiri dari tiga aras yaitu V1 (varietas Tantyna F1), V2 (varietas Tombatu F1) dan V3 (varietas Betavila $\mathrm{F} 1)$. Faktor kedua adalah beberapa dosis pupuk bokashi kotoran ayam $(\mathrm{P})$ yang terdiri dari 4 taraf yaitu P1 (10 ton/ha), P2 (15 ton/ha), P3 (20 ton/ha) dan P4 (25 ton/ha). Setiap petak perlakuan terdapat 12 tanaman dan diantaranya terdapat 5 tanaman sampel. Data dianalisis dengan analisis ragam pada taraf nyata $5 \%$ dan untuk mengetahui perbedaan antar perlakuan menggunakan uji BNJ pada taraf $5 \%$. Hasil penelitian menunjukkan bahwa pertumbuhan dan produksi tanaman tomat terbaik di jumpai pada perlakuan interaksi varietas Betavila F1 dan dosis pupuk bokashi kotoran ayam 15 ton/ha. Perlakuan varietas terbaik pada pertumbuhan dan produksi tanaman tomat di jumpai pada varietas Betavila. Perlakuan dosis pupuk bokashi kotoran ayam terbaik pada pertumbuhan dan produksi tanaman tomat di jumpai pada dosis pupuk 15 ton per ha.

Keywords: varietas, pupuk bokashi, tanaman tomat, Desa Airmadidi, Kabupaten Minahasa Utara. 


\section{PENDAHULUAN}

\section{Latar Belakang}

Tomat (Solanum lycopersicum. L) adalah salah satu komoditas pertanian yang sangat bermanfaat bagi tubuh manusia karena mengandung vitamin dan mineral yang diperlukan untuk pertumbuhan dan kesehatan. Buah tomat mengandung karbohidrat, protein, lemak dan kalori. Buah tomat merupakan komoditas multiguna yang berfungsi sebagai sayuran, bumbu masak, buah meja, penambah nafsu makan, bahan pewarna makanan, sampai kepada bahan kosmetik dan obat-obatan. Sebagai sumber mineral, buah tomat dapat bermanfaat untuk pembentukan tulang dan gigi (zat kapur dan fospor), sedangkan zat besi (Fe) yang terkandung di dalam buah tomat dapat berfungsi untuk pembentukan sel darah merah. Selain itu tomat mengandung zat potassium yang sangat bermanfaat untuk menurunkan gejala tekanan darah tinggi (Cahyono 2005). Oleh karena itu, permintaan komoditas tomat terus meningkat seiring dengan semakin bertambahnya jumlah penduduk dan kesadaran masyarakat terhadap pentingnya kesehatan.

Luas panen tanaman tomat di Indonesia tahun 2014 sebesar 59.008 ha dengan jumlah produksi sebanyak 915.987 ton serta produktifitasnya 15,52 ton per ha, dengan sentra produksi di Pulau Jawa (Direktorat Jenderal Hortikultura, 2014). Luas panen tanaman tomat di Sulawesi Utara tahun 2014 seluas 2.519 ha dengan jumlah produksi tahun 2014 sebanyak 28.124 ton serta produktifitasnya 11,16 ton per ha (Direktorat Jenderal Hortikultura, 2014). Luas panen tanaman tomat di Desa Airmadidi Kecamatan Airmadidi Kabupaten Minahasa Utara 13 ha dengan jumlah produksi 56,5 ton dan produktifitasnya 4,34 ton per ha (Dinas Pertanian, Peternakan dan Perkebunan Kabupaten Minahasa Utara 2014). Melihat tingginya hasil panen tomat Nasional dibanding rendahnya produksi tomat Kabupaten Minahasa utara di desa Airmadidi, kemungkinan disebabkan varietas yang ditanam tidak cocok, kultur teknis yang kurang baik dan pemberantasan hama penyakit yang kurang efisien serta pemupukan yang tidak berimbang.

Salah satu cara yang ditempuh untuk meningkatkan hasil produksi tanaman tomat adalah dengan menggunakan pupuk bokashi kotoran ayam yang merupakan salah satu alternatif dalam penerapan teknologi pertanian organik yang berwawasan lingkungan dan berkelanjutan. Pupuk bokashi kotoran ayam mempunyai prospek yang baik untuk dijadikan pupuk organik karena mempunyai kandungan unsur hara yang cukup tinggi. Penggunaan bokashi kotoran ayam telah diteliti antara lain oleh Pangaribuan dkk (2012) yang menunjukkan bahwa pupuk bokashi kandang ayam yang dikombinasikan dengan setengah dosis pupuk rekomendasi dapat meningkatkan hasil tomat dibandingkan dengan bokashi pupuk kandang kambing, sapi dan kuda.. Bokashi kotoran ayam adalah bokashi yang terbaik diantara semua jenis bokashi kotoran ternak. Pupuk bokashi kotoran ayam diharapkan dapat mendukung usaha pertanian dan bisa mengatasi kelangkaan serta mahalnya pupuk buatan (anorganik).

Berdasarkan hasil penelitian dari Pangaribuan dan Hidayat Pujisiswanto (2008) menunjukkan bahwa aplikasi pupuk bokashi kotoran ayam mampu meningkatkan konsentrasi hara dalam tanah, terutama $\mathrm{N}, \mathrm{P}$ dan $\mathrm{K}$ serta unsur hara lainnya. Selain itu pupuk bokashi kotoran ayam dapat memperbaiki tata udara tanah dan air tanah, dengan demikian perakaran tanaman akan berkembang dengan baik dan akar dapat menyerap unsur hara yang lebih banyak terutama unsur hara $\mathrm{N}$ yang akan meningkatkan pertumbuhan dan produksi tomat. penambahan pupuk organik (pupuk bokashi kotoran ayam ) kedalam tanah dan penggunaan varietas yang berdaya hasil tinggi serta cocok dengan lingkungan yang ada. Hasil penelitian Abiddin dkk (2013) menunjukkan bahwa tanaman tomat varietas Rempai merupakan varietas yang paling baik pertumbuhannya dan menghasilkan produksi yang optimal dibandingkan dengan varietas Vida dan Super king. Dosis pupuk kandang yang optimum untuk meningkatkan pertumbuhan dan produksi tanaman tomat terdapat pada perlakuan P2 (500 gram/polybag). Interaksi antara varietas tomat dataran rendah dan dosis pupuk kandang dapat memberikan respos yang positif terhadap pertumbuhan dan produksi tanaman tomat. Pemberian pupuk kandang dapat menyumbangkan unsur hara bagi tanaman serta meningkatkan serapan unsur hara oleh tanaman Wigati dkk (2006). Firmanto (2011) menyatakan pupuk kandang yang telah masak sebanyak 15-20 ton / ha diberikan bersamaan dengan pengolahan lahan untuk budidaya tomat. Kotoran ayam merupakan salah satu pupuk kandang yang sering digunakan 
oleh petani saat ini. Menurut Hasibuan (2004) bahwa secara keseluruhan kotoran ayam mengandung 55\% $\mathrm{H}_{2} \mathrm{O} ; 1,00 \% \mathrm{~N} ; 0,80 \% \mathrm{P}_{2} \mathrm{O}_{5}$ dan $0,04 \% \mathrm{~K}_{2} \mathrm{O}$. Pupuk kandang ayam memiliki kandungan nitrogen dan fosfat yang paling tinggi dibandingkan dengan pupuk kandang lainnya.

Selain itu pupuk kandang dapat menghasilkan hormon sitokinin dan giberalin yang dapat merangsang pertumbuhan tanaman. Berdasarkan latar belakang tersebut maka penulis tertarik untuk melakukan penelitian dengan judul Analisis pengaruh beberapa dosis pupuk bokashi kotoran ayam terhadap pertumbuhan dan produksi tiga varietas tanaman tomat (Solanum lycopersicum L.) di Desa Airmadidi, Kabupaten Minahasa Utara.

\section{Tujuan penelitian}

1. Untuk menganalisis pengaruh interaksi tiga varietas tomat (Solanum lycopersicum L.) dengan beberapa dosis pupuk bokashi kotoran ayam terhadap pertumbuhan Airmadidi Kabupaten Minahasa Utara.

2. Untuk mendapatkan varietas yang paling baik dan produksi tomat di Desa terhadap peningkatkan pertumbuhan dan produksi yang maksimal pada tanaman tomat (Solanum lycopersicum L.) di DesaAirmadidi Kabupaten Minahasa Utara.

3. Untuk mengetahui pengaruh salah satu dosis pupuk bokashi kotoran ayam terhadap peningkatkan pertumbuhan dan produksi yang maksimal pada tanaman tomat (Solanum lycopersicum L.) di Desa Airmadidi Kabupaten Minahasa Utara.

\section{METODOLOGI PENELITIAN}

\section{Waktu dan tenpat penelitian}

Penelitian ini dilaksanakan pada bulan Oktober 2016 sampai bulan Februari 2017 di kebun percobaan Fakultas Pertanian Universitas Klabat Airmadidi Kabupaten Minahasa utara

\section{Bahan dan Alat}

Bahan yang dipakai antara lain benih tomat varietas Tantyna F1, Tombatu F1 dan Betavila F1, pupuk kotoran ayam, dedak, sekam padi, furadan, insektisida, sevin $85 \mathrm{~S}$, fungisida Dithane M-45, bakterisida, gula merah, EM4, kertas label, air, tanah dan lain-lain. yang digunakan seperti cangkul, ajir, alat pengukur berat (timbangan analitik), tali plastik, plastik, parang, pisau, gembor, alat pengukur panjang (meter), alat pengukur diameter batang dan buah (jangka sorong), slangk, hand sprayer volune 14 liter, baki pesemaian, ember, gayung, alat tulis menulis, gunting, kalkulator, kamera digital dan lain-lain.

\section{Metode Penelitian}

Penelitian ini dilaksanakan dalam percobaan faktorial yang dirancang secara acak kelompok (RAK) dengan masing-masing kombinasi perlakuan diulang tiga kali. Faktor pertama adalah varietas tomat $(\mathrm{V})$ yang terdiri dari tiga aras yaitu V1 (varietas Tantyna F1), V2 (varietas Tombatu F1) dan V3 (varietas Betavila F1). Faktor kedua adalah beberapa dosis pupuk bokashi kotoran ayam (P) yang terdiri dari 4 aras yaitu P1 (10 ton/ha), P2 (15 ton/ha), P3 (20 ton/ha) dan P4 (25 ton/ha). Setiap petak perlakuan terdapat 12 tanaman dan diantaranya terdapat 5 tanaman sampel.

\section{Prosedur Kerja} meliputi:

Langkah-langkah pelaksanaan di lapang

1) pembuatan pupuk bokashi kotoran ayam.

2) analisis kimia tanah awal sebelum dan sesudah penelitian,

3) analisis bokashi kotoran ayam sesudah pengomposan,

4) pesemaian,

5) pengolahan tanah,

6) pemupukan,

7) penanaman,

8) pemasangan ajir

9) pemangkasan,

10) penyiangan,

11) pengairan

12) pemberantasan hama dan penyakit

13) panen.

\section{Variabel yang diamati}

Pengamatan dilakukan pada tinggi tanaman $(\mathrm{cm})$, diameter batang $(\mathrm{cm})$, jumlah daun, jumlah bunga, jumlah cabang produksi, jumlah tandan buah pada umur 30, 40 dan 50 hari sesudah tanam (hst), jumlah buah, berat buah (gram) dan diameter buah $(\mathrm{cm})$ pada umur $60,65,70,75$ dan 80 hst. 


\section{Analisis data}

Data hasil pengamatan dianalisis berdasarkan analisis ragam, dilanjutkan dengan uji BNJ $5 \%$ untuk mengetahui perbedaan antar perlakuan.

\section{HASIL DAN PEMBAHASAN}

Penelitian dimana kesuburan tanah lokasi penelitian menunjukkan $\mathrm{C} / \mathrm{N}$ yang relatif sedang, yaitu 11,80 dan tingkat kemasaman 6.30 dengan kriteria agak masam. Hasil analisis bokashi kotoran ayam sebelum aplikasi di lapang disajikan pada Tabel 1. Bahan organik bokashi kotoran ayam menunjukkan Nilai C/N 18,94 dengan kriteria tinggi yang berarti bokashi tersebut sudah terdekomposisi sempurna. Hasil analisis kimia tanah sesudah penelitian disajikan pada Tabel 1 . mHasil analisis tanah awal secara umum menunjukkan bahwa status kesuburan tanah di lokasi penelitian termasuk rendah dengan reaksi tanah agak masam dan kandungan unsur hara makro $\mathrm{N}$ sedang, $\mathrm{P}$ rendah dan $\mathrm{K}$ sedang (Tabel $1)$.

\section{Tinggi tanaman}

Berdasarkan hasil analisis ragam menunjukkan bahwa interaksi varietas dan dosis pupuk bokashi kotoran ayam tidak memberikan pengaruh yang nyata terhadap tinggi tanaman pada umur 30, 40 dan 50 hst. Namun pada umur 50 hst tanaman tertinggi ditunjukkan oleh varietas Tantyna (V1) dan dosis pupuk 15 ton/ha (P2) pada plot (V1 P2) dengan tinggi tanaman (128,7 $\mathrm{cm})$. Selanjutnnya perlakuan varietas tanaman tomat tidak memberikan pengaruh yang nyata terhadap tinggi tanaman pada umur 30, 40 dan 50 hst. pada umur 50 hst tanaman tertinggi ditunjukkan oleh varietas Betavila (V3) dengan tinggi tanaman $(125,00 \mathrm{~cm})$. Demikian pula perlakuan dosis pupuk bokashi kotoran ayam tidak memberikan pengaruh yang nyata terhadap tinggi tanaman pada umur 30, 40 dan 50 hst. pada umur 50 hst tanaman tertinggi ditunjukkan oleh dosis pupuk 25 ton perha (P4) dengan tinggi tanaman $(124,2 \mathrm{~cm})$.

\section{Diameter batang}

Hasil analisis ragam menunjukkan ada interaksi antara perlakuan varietas dengan dosis pupuk bokashi kotoran ayam terhadap diameter batang pada umur 40 hst. diameter batang tertinggi oleh varietas Betavila (V3) dan dosis pupuk 15 ton/ha (P2) pada plot (V3 P2) dengan ukuran diameter batang $(1,74 \mathrm{~cm})$. Rara - rata diameter batang tanaman tomat dapat dilihat pada Tabel 2. Berdasarkan hasil analisis ragam menunjukkan bahwa perlakuan tiga varietas tanaman tomat memberikan pengaruh yang nyata terhadap diameter batang tomat pada umur 40 dan 50 hst. pada umur 40 hst diameter batang tertinggi ditunjukkan oleh varietas Betavila (V3) dengan ukuran diameter batang $(1,58 \mathrm{~cm})$. pada umur 50 hst diameter tertinggi ditunjukkan oleh varietas Betavila (V3) dengan ukuran diameter batang $(1,72 \mathrm{~cm})$. Rata - rata diameter batang tanaman tomat dapat dilihat pada Tabel 3.

\section{Jumlah daun}

Hasil analisis ragam menunjukkan ada interaksi antara perlakuan varietas dengan dosis pupuk bokashi kotoran ayam terhadap jumlah

daun. pada umur 50 hst jumlah daun tertinggi ditunjukkan oleh varietas Tantyna (V1) dengan dosis pupuk 10 ton/ha (P1) pada plot (V1P1) dengan jumlah daun (55.40 helai daun. Rata - rata jumlah daun tanaman tomat terdapat pada Tabel 4.

Hasil analisis ragam menunjukkan bahwa perlakuan varietas berpengaruh nyata terhadap jumlah daun tanaman tomat pada umur $30 \mathrm{hst}$, jumlah daun tertinggi ditunjukkan oleh perlakuan varietas Tantyna (V1) dengan banyaknya daun (12,22 helai daun). Pada umur 50 hst jumlah daun tertinggi di tunjukkan oleh perlakuan varietas Tantyna (V1) dengan banyaknya daun $(52,28$ helai daun). Perlakuan pupuk bokashi berpengaruh nyata terhadap jumlah daun pada umur 40 hst. jumlah daun tertinggi ditunjukkan oleh perlakuan dosis pupuk bokashi 20 ton per ha (P3) dengan jumlah daun (40,29 helai daun). Pada umur 50 hst jumlah daun tertinggi ditunjukkan oleh perlakuan dosis pupuk bokashi 20 ton perha (P3) dengan jumlah daun $(51,62$ helai daun). Rata - rata jumlah daun tanaman tomat terhadap perlakuan varietas dan perlakuan pupuk pada umur 30, 40 dan 50 hst dapat di lihat pada Tabel 5 .

\section{Jumlah bunga}

Hasil analisis ragam menunjukkan bahwa perlakuan varietas berpengaruh nyata terhadap jumlah bunga tanaman tomat pada umur 30 dan 40 hst. pada umur 30 hst jumlah bunga tertinggi 
ditunjukkan oleh perlakuan varietas Betavila (V3) dengan jumlah bunga (32,62 bunga). Pada umur 40 hst jumlah bunga tertinggi ditunjukkan oleh perlakuan varietas betavila (V3) dengan jumlah bunga (38,62 bunga). Rata - rata jumlah bunga tanaman tomat dapat dilihat pada tabel 6 .

\section{Jumlah cabang produksi}

Hasil analisis ragam menunjukkan bahwa ada interaksi antara perlakuan varietas dengan dosis pupuk bokashi kotoran ayam terhadap jumlah cabang produksi pada umur 30 hst. jumlah cabang produksi tertinggi pada umur 30 hst ditunjukkan oleh perlakuan interaksi varietas Betavila (V3) dengan dosis pupuk bokashi 10 ton/ha (P1) pada plot (V3 P1) dengan jumlah cabang produksi (4,70 cabang produksi). Perlakuan varietas berpengaruh nyata terhadap jumlah cabang produksi tanaman tomat pada umur 30 dan 40 hst. Pada umur 30 hst cabang produksi tertinggi ditunjukkan oleh perlakuan varietas Betavila (V3) dengan jumlah cabang produksi (4,30 cabang produksi). Pada umur 40 hst cabang produksi tertinggi ditunjukkan oleh perlakuan varietas Betavila (V3) dengan jumlah cabang produksi (4,78 cabang produksi). Rata rata jumlah cabang produksi tanaman tomat dapat dilihat pada tabel 7 .

\section{Jumlah tandan buah}

Hasil analisis ragam menunjukkan bahwa ada interaksi antara perlakuan varietas dengan dosis pupuk bokashi kotoran ayam terhadap jumlah tandan buah pada umur 50 hst. jumlah tandan buah tertinggi ditunjukkan oleh varietas Tantyna (V1) dengan dosis pupuk 10 ton/ha (P1) pada plot (V1P1) dengan jumlah tandan buah (11,13 tandan buah). Perlakuan varietas berpengaruh nyata terhadap jumlah tandan buah tanaman tomat pada umur 30 dan 50 hst pada umur 30 hst jumlah tandan buah tertinggi ditunjukkan oleh varietas betavila (V3) dengan jumlah tandan buah (6,89 tandan buah). Pada umur 50 hst jumlah tandan buah tertinggi ditunjukkan oleh perlakuan varietas Tantyna (V1) dengan jumlah tandan buah (9,35 tandan buah). Rata - rata jumlah tandan buah tanaman tomat dapat dilihat pada Tabel 8 .

\section{Jumlah buah}

Hasil analisis ragam menunjukkan bahwa Perlakuan varietas berpengaruh nyata terhadap jumlah buah tanaman tomat pada umur $60,65,70$ dan 80 hst. pada umur 60 hst jumlah buah tertinggi ditunjukkan oleh perlakuan varietas Tantyna (V1) dengan jumlah buah (3,4 buah). Pada umur 65 hst jumlah buah tertinggi ditunjukkan oleh perlakuan varietas Tantyna (V1) dengan jumlah buah (16,0 buah). Pada umur 70 hst jumlah buah tertinggi ditunjukkan oleh perlakuan varietas Tantyna (V1) dengan jumlah buah (41,2 buah. Pada umur 80 hst jumlah buah tertinggi ditunjukkan oleh perlakuan varietas Betavila (V3) dengan jumlah buah (66,0 buah). Rata - rata jumlah buah tanaman tomat dapat dilihat pada tabel 9.

\section{Berat buah}

Hasil analisis ragam menunjukkan bahwa perlakuan varietas berpengaruh nyata terhadap berat buah tanaman tomat pada umur 60, 70, 75 dan 80 hst. Pada umur 60 hst berat buah tertinggi ditunjukkan oleh perlakuan varietas Tantyna (V1) dengan berat buah $(37,84$ gram berat buah). Pada umur70 hst Jumlah berat buah tertinggi di tunjukkan oleh perlakuan varietas Tombatu (V2) dengan jumlah berat buah (80,46 gram). Pada umur 75 hst berat buah tertinggi di tunjukkan oleh perlakuan varietas Tombatu (V2) dengan jumlah berat buah (73,56 gram). Pada umur 80 hst berat buah tertinggi di tunjukkan oleh perlakuan varietas Tombatu (V2) dengan jumlah berat buah $(52,70$ gram $)$. perlakuan pupuk bokashi berpengaruh nyata terhadap berat buah pada umur 70 hst, jumlah berat buah tertinggi ditunjukkan oleh perlakuan dosis pupuk bokashi 20 ton perha (P3) dengan jumlah berat buah (68,0 gram). Rata - rata berat buah tomat dapat dilihat pada tabel 10 .

\section{Diameter buah}

Hasil analisis ragam menunjukkan Perlakuan varietas berpengaruh nyata terhadap diameter buah tanaman tomat pada umur 65,70 dan 75. pada umur 65 hst diameter buah tertinggi ditunjukkan oleh perlakuan varietas Tantyna (V1) sebesar $(4,66 \mathrm{~cm})$ diameter buah. Pada umur 70 hst diameter buah tertinggi ditunjukkan oleh perlakuan varietas Tombatu (V2) dengan ukuran diameter buah (4,76 gram). Pada umur 75 hst diameter tertinggi ditunjukkan oleh perlakuan varietas Tombatu (V2) dengan ukuran diameter buah $(4,75 \mathrm{~cm})$. Rata - rata diameter buah tanaman tomat dapat dilihat pada tabel 11 . 
Tabel 1. Hasil analisis kimia tanah awal sebelum dan sesudah penelitian serta analisis bokashi kotoran ayam sesudah pengomposan.

\begin{tabular}{llll}
\hline \multicolumn{1}{c}{ Nama unsur } & $\begin{array}{l}\text { Analisis } \\
\text { sebelum penelitian }\end{array}$ & $\begin{array}{l}\text { tanah } \\
\text { anam sesudah pengomposan }\end{array}$ & $\begin{array}{l}\text { Analisis tanah sesudah } \\
\text { penelitian }\end{array}$ \\
\hline pH H2O (1:2,5) & 6,30 agak masam & 6,70 netral & 6,45 agak masam \\
N (\%) Kjeldah & 0,21 sedang & 0,70 tinggi & 0,17 rendah \\
P Bray-1 (ppm) & 15,46 rendah & 0,32 sangat rendah & 13,66 rendah \\
KO2 Bray $-1(\mathrm{ppm})$ & 28,59 sedang & 0,34 sangat rendah & 39,53 sedang \\
C-organik $(\%)$ & 2,48 sedang & 13,26 sangat tinggi & 2,15 sedang \\
Nisbah C/N & 11,80 sedang & 18,94 tinggi & 12,64 sedang \\
\hline
\end{tabular}

Sumber: Laboratorium Tanah Fakultas Pertanian Universitas Sam Ratulangi Manado (2017) Catatan: Penilaian sifat-sifat kimia tanah berdasarkan kriteria Pusat Penelitian Tanah 1983.

Tabel 2. Rata - rata diameter batang tanaman tomat interaksi varietas dengan Pupuk pada umur 40 hst.

\begin{tabular}{lllll}
\hline & \multicolumn{4}{c}{ Pupuk bokashi kotoran ayam } \\
\hline Varietas & P1 notasi & P2 notasi & P3 notasi & P4 notasi \\
\hline V 1 = Tantyna & $1,40 \mathrm{ab}$ & $1,51 \mathrm{abc}$ & $1,67 \mathrm{bc}$ & $1,49 \mathrm{abc}$ \\
V 2 = Tombatu & $1,36 \mathrm{a}$ & $1,34 \mathrm{a}$ & $1,39 \mathrm{ab}$ & $1,44 \mathrm{ab}$ \\
V 3 = Betavila & $1,51 \mathrm{abc}$ & $1,74 \mathrm{c}$ & $1,57 \mathrm{abc}$ & $1,49 \mathrm{abc}$ \\
BNJ 5\% = 0,28 & & & &
\end{tabular}

Ket: Angka-angka yang diikuti huruf yang sama menunjukkan tidak berbeda nyata berdasarkan uji BNJ pada taraf $5 \%$.

Tabel 3. Rata-rata diameter batang tanaman tomat pada perlakuan tiga varietas pada umur 30, 40 dan 50 hst.

\begin{tabular}{|c|c|c|c|}
\hline \multirow[t]{2}{*}{ Perlakuan } & \multicolumn{3}{|c|}{ Umur ( HST ) } \\
\hline & 30 notasi & 40 notasi & 50 notasi \\
\hline \multicolumn{4}{|l|}{ Varietas } \\
\hline V 1 = Tantyna & $1,12 \mathrm{a}$ & $1,53 \mathrm{~b}$ & $1,64 \mathrm{ab}$ \\
\hline V $2=$ Tombatu & $1,12 \mathrm{a}$ & $1,53 \mathrm{~b}$ & $1,52 \mathrm{a}$ \\
\hline V $3=$ Betavila & $1,18 \mathrm{a}$ & $1,58 \mathrm{~b}$ & $1,72 \mathrm{~b}$ \\
\hline Nilai BNJ $5 \%$ & 0,09 & 0,09 & 0,14 \\
\hline
\end{tabular}

Ket: Angka-angka yang diikuti huruf yang sama menunjukkan tidak berbeda nyata berdasarkan uji BNJ pada taraf $5 \%$.

Tabel 4. Rata - rata jumlah daun tanaman tomat terhadap perlakuan interaksi Varietas dengan pupuk pada umur 50 hst.

\begin{tabular}{llccc}
\hline Perlakuan & \multicolumn{5}{c}{ Pupuk bokashi kotoran ayam } \\
\hline Varietas & P1 notasi & P2 notasi & P3 notasi & P4 notasi \\
\hline V 1 = Tantyna & $55,40 \mathrm{~b}$ & $43,80 \mathrm{ab}$ & $54,80 \mathrm{~b}$ & $55,13 \mathrm{~b}$ \\
V 2 = Tombatu & $40,00 \mathrm{a}$ & $38,20 \mathrm{a}$ & $51,40 \mathrm{ab}$ & $47,33 \mathrm{ab}$ \\
V 3 = Betavila & $40,53 \mathrm{a}$ & $49,47 \mathrm{ab}$ & $48,67 \mathrm{ab}$ & $48,13 \mathrm{ab}$ \\
BNJ 5\% $=13,73$ & & & & \\
\hline
\end{tabular}

Ket: Angka-angka yang diikuti huruf yang sama menunjukkan tidak berbeda nyata berdasarkan uji BNJ pada taraf $5 \%$. 
Tabel 5. Rata - rata jumlah daun tanaman tomat terhadap perlakuan varietas dan perlakuan pupuk pada umur 30, 40 dan 50 hst.

\begin{tabular}{|c|c|c|c|}
\hline Perlakuan & 30 notasi & 40 notasi & 50 notasi \\
\hline \multicolumn{4}{|l|}{ Varietas } \\
\hline V 1 = Tantyna (V1) & $12,22 \mathrm{~b}$ & $39,30 \mathrm{a}$ & $52,28 \mathrm{a}$ \\
\hline V $2=$ Tombatu (V2) & $11,53 \mathrm{a}$ & $37,53 \mathrm{a}$ & $44,23 \mathrm{~b}$ \\
\hline V $3=$ Betavila (V3) & $12,10 \mathrm{ab}$ & 38,55 a & $46,70 \mathrm{~b}$ \\
\hline Nilai BNJ $5 \%$ & 0,60 & 4,1 & 4,62 \\
\hline \multicolumn{4}{|l|}{ Pupuk Bokashi } \\
\hline 10 ton per ha $(\mathrm{P} 1)$ & $12,22 \mathrm{p}$ & $38,60 \mathrm{pq}$ & $45,31 \mathrm{pq}$ \\
\hline 15 ton per ha $(\mathrm{P} 2)$ & $11,67 \mathrm{p}$ & $35,27 \mathrm{p}$ & $43,82 \mathrm{p}$ \\
\hline 20 ton per ha (P3) & $12,00 \mathrm{p}$ & $39,69 \mathrm{pq}$ & $50,20 \mathrm{qr}$ \\
\hline 25 ton perha $(\mathrm{P} 4)$ & $12,00 \mathrm{p}$ & $39,69 \mathrm{pq}$ & $50,20 \mathrm{qr}$ \\
\hline Nilai BNJ $5 \%$ & 0,78 & 5,36 & 6,04 \\
\hline
\end{tabular}

Ket: Angka-angka yang diikuti huruf yang sama menunjukkan tidak berbeda nyata berdasarkan uji BNJ pada taraf $5 \%$.

Tabel 6. Rata - rata jumlah bunga tanaman tomat terhadap perlakuan varietas pada umur 30, 40 dan 50 hst.

\begin{tabular}{llll}
\hline \multicolumn{1}{c}{ Jumlah bunga } & \multicolumn{1}{c}{ Umur ( HST ) } \\
\hline Perlakuan & 30 Notasi & $\mathbf{4 0}$ Notasi & $\mathbf{5 0}$ Notasi \\
\hline Varietas & & & $18,12 \mathrm{a}$ \\
\hline V 1 = Tantyna (V1) & $30,35 \mathrm{a}$ & $29,08 \mathrm{a}$ & $17,97 \mathrm{a}$ \\
V 2 = Tombatu (V2) & $22,15 \mathrm{~b}$ & $35,18 \mathrm{ab}$ & $19,27 \mathrm{a}$ \\
V 3 = Betavila (V3) & $32,62 \mathrm{a}$ & $38,62 \mathrm{~b}$ & 4,18 \\
Nilai BNJ 5 \% & 8,31 & 6,59 & \\
\hline
\end{tabular}

Ket: Angka-angka yang diikuti huruf yang sama menunjukkan tidak berbeda nyata berdasarkan uji BNJ pada taraf $5 \%$.

Tabel 7. Rata - rata jumlah cabang produksi tanaman tomat terhadap interaksi varietas dan pupuk pada umur 30 hst dan perlakuan varietas pada umur 30, 40 dan 50 hst.

\begin{tabular}{|c|c|c|c|c|}
\hline & & Pupuk bc & pran ayam & \\
\hline Varietas & P 1 notasi & P 2 notasi & P3 notasi & P4 notasi \\
\hline V 1 = Tantyna & $4,43 a b$ & $4,17 \mathrm{ab}$ & $4,13 \mathrm{ab}$ & $4,27 \mathrm{ab}$ \\
\hline V $2=$ Tombatu & $3,83 \mathrm{ab}$ & 3,57 a & $4,27 \mathrm{ab}$ & $3,90 \mathrm{ab}$ \\
\hline V $3=$ Betavila & $4,70 \mathrm{~b}$ & $4,43 \mathrm{ab}$ & $3,63 \mathrm{ab}$ & $4,43 \mathrm{ab}$ \\
\hline BNJ $5 \%=1,10$ & $4,43 \mathrm{ab}$ & $4,17 \mathrm{ab}$ & $4,13 \mathrm{ab}$ & $4,27 \mathrm{ab}$ \\
\hline Perlakuan Umur ( & & & & \\
\hline & 30 Notasi & 40 Notasi & 50 Notasi & \\
\hline Varietas & & & & \\
\hline V 1 = Tantyna (V1) & $4,25 \mathrm{pq}$ & $4,22 \mathrm{pq}$ & $4,55 \mathrm{p}$ & \\
\hline V 2 = Tombatu (V2) & $3,89 \mathrm{p}$ & $4,12 \mathrm{p}$ & $4,73 \mathrm{p}$ & \\
\hline V $3=$ Betavila (V3) & $4,30 \mathrm{q}$ & $4,78 \mathrm{q}$ & $5,02 \mathrm{p}$ & \\
\hline Nilai BNJ $5 \%$ & 0,37 & 0,63 & 0,49 & \\
\hline
\end{tabular}

Ket: Angka-angka yang diikuti huruf yang sama menunjukkan tidak berbeda nyata berdasarkan uji BNJ pada taraf $5 \%$. 
Tabel 8. Rata - rata jumlah tanaman dan buah tanaman tomat terhadap perlakuan interaksi varietas dan pupuk pada umur 50 hst dan perlakuan varietas pada umur 30, 40 dan 50 hst.

\begin{tabular}{lllll}
\hline & \multicolumn{4}{c}{ Pupuk bokashi kotoran ayam } \\
\hline Varietas & P 1 notasi & P 2 notasi & P3 notasi & P4 notasi \\
V 1 = Tantyna & $11,13 \mathrm{a}$ & $8,13 \mathrm{ab}$ & $9,13 \mathrm{ab}$ & $9,00 \mathrm{ab}$ \\
V 2 = Tombatu & $7,13 \mathrm{ab}$ & $6,87 \mathrm{ab}$ & $9,27 \mathrm{ab}$ & $6,73 \mathrm{~b}$ \\
V 3 = Betavila & $7,20 \mathrm{ab}$ & $9,80 \mathrm{ab}$ & $8,47 \mathrm{ab}$ & $9,07 \mathrm{ab}$ \\
BNJ 5 \% = 1,10 & & & & \\
& 30 Notasi & 40 Notasi & 50 Notasi & \\
\hline Varietas & & & & \\
\hline V 1 = Tantyna (V1) & $6,33 \mathrm{pq}$ & $6,35 \mathrm{p}$ & $9,35 \mathrm{p}$ & \\
V 2 = Tombatu (V2) & $5,98 \mathrm{p}$ & $5,98 \mathrm{p}$ & $7,50 \mathrm{q}$ & \\
V 3 = Betavila(V3) & $6,89 \mathrm{q}$ & $7,32 \mathrm{p}$ & $8,63 \mathrm{pq}$ & \\
Nilai BNJ 5 \% & 0,80 & 1,34 & 1,46 & \\
\hline
\end{tabular}

Ket: Angka-angka yang diikuti huruf yang sama menunjukkan tidak berbeda nyata berdasarkan uji BNJ pada taraf $5 \%$.

Tabel 9. Rata - rata jumlah buah tomat terhadap varietas pada umur 60, 65, 70, 75 dan 80 hst.

\begin{tabular}{|c|c|c|c|c|c|c|}
\hline \multirow[t]{2}{*}{ Perlakuan } & \multicolumn{6}{|c|}{ Umur ( HST ) } \\
\hline & 60 notasi & 65 notasi & 70 notasi & 75 notasi & 80 notasi & Total notasi \\
\hline Varietas & & & & & & \\
\hline V 1 = Tantyna & $3,4 \mathrm{~b}$ & $16,0 \mathrm{a}$ & 41,2 a & 48,2 & 33,42 a & $142,2 \mathrm{~b}$ \\
\hline $\mathrm{V} 2=$ Tombatu & $0,4 \mathrm{a}$ & $0,2 \mathrm{~b}$ & $12,3 \mathrm{~b}$ & 44,0 a & 40,5 a & $79,4 \quad a$ \\
\hline V 3 = Betavila & $1,5 \mathrm{ab}$ & $1,3 \mathrm{~b}$ & $21,7 \quad b$ & 59,2 a & $66,0 \mathrm{~b}$ & $149,7 \mathrm{~b}$ \\
\hline BNJ $5 \%=13,73$ & 2,30 & 2,67 & 11,20 & 15,50 & 24,7 & 11,27 \\
\hline
\end{tabular}

Ket: Angka-angka yang diikuti huruf yang sama menunjukkan tidak berbeda nyata berdasarkan uji BNJ pada taraf $5 \%$.

Tabel 10. Rata - rata berat buah tanaman tomat (gram) terhadap perlakuan varietas dan perlakuan pupuk pada umur $60,65,70,75$ dan 80 hst.

\begin{tabular}{|c|c|c|c|c|c|c|}
\hline \multirow[t]{2}{*}{ Perlakuan } & \multicolumn{6}{|c|}{ Umur ( HST ) } \\
\hline & 60 notasi & 65 notasi & 70 notasi & 75 notasi & 80 notasi & Total notasi \\
\hline \multicolumn{7}{|l|}{ Varietas } \\
\hline V 1 = Tantyna & $37,84 \mathrm{~b}$ & $64,80 \mathrm{a}$ & $56,17 \mathrm{a}$ & $46,60 \mathrm{a}$ & 38,65 a & $244,06 \mathrm{~b}$ \\
\hline V 2 = Tombatu & $19,08 \mathrm{a}$ & $10,25 \mathrm{a}$ & $80,46 \mathrm{~b}$ & $73,56 \mathrm{~b}$ & $52,70 \quad b$ & $236,05 \mathrm{~b}$ \\
\hline V 3 = Betavila & $10,47 \mathrm{a}$ & $18,42 \mathrm{a}$ & $61,95 \mathrm{a}$ & 51,52 a & 40,26 & $10,47 \quad \mathrm{a}$ \\
\hline BNJ $5 \%=13,73$ & 24,79 & 20,38 & 9,66 & 10,17 & 7,73 & 14,54 \\
\hline \multicolumn{7}{|l|}{ Pupuk Bokashi } \\
\hline 10 ton per ha $(\mathrm{P} 1)$ & $23,2 \mathrm{p}$ & $28,0 \mathrm{p}$ & $67,6 \mathrm{q}$ & $57,8 \mathrm{p}$ & $44,26 \mathrm{p}$ & $220,86 \mathrm{p}$ \\
\hline 15 ton per ha $(\mathrm{P} 2)$ & $19,3 \mathrm{p}$ & $32,0 \mathrm{p}$ & $61,6 \mathrm{p}$ & $55,9 \mathrm{p}$ & $42,34 \mathrm{p}$ & $211,14 \mathrm{p}$ \\
\hline 20 ton per ha (P3) & $26,0 \mathrm{p}$ & $39,7 \mathrm{p}$ & $68,0 \mathrm{q}$ & $54,8 \mathrm{p}$ & $40,30 \mathrm{p}$ & $228,80 \mathrm{p}$ \\
\hline 25 ton perha $(\mathrm{P} 4)$ & $21,4 \mathrm{p}$ & $25,1 \mathrm{p}$ & $67,6 \mathrm{q}$ & $60,4 p$ & $48,58 \mathrm{p}$ & $223,08 \mathrm{p}$ \\
\hline Nilai BNJ $5 \%$ & 32,41 & 26,65 & 12,63 & 13,3 & 10,1 & 19,01 \\
\hline
\end{tabular}

Ket: Angka-angka yang diikuti huruf yang sama menunjukkan tidak berbeda nyata berdasarkan uji BNJ pada taraf $5 \%$. 
Tabel 11. Rata - rata diameter buah tanaman tomat $(\mathrm{cm})$ terhadap perlakuan varietas pada umur $60,65,70,75$ dan 80 hst.

\begin{tabular}{llllll}
\hline \multicolumn{1}{c}{ Perlakuan } & \multicolumn{5}{c}{ Umur ( HST ) } \\
\hline \multicolumn{1}{l}{ Varietas } & 60 notasi & $\mathbf{6 5}$ notasi & 70 notasi & $\mathbf{7 5}$ notasi & $\mathbf{8 0 ~ n o t a s i}$ \\
\hline V 1 = Tantyna & $3,35 \mathrm{a}$ & $4,66 \mathrm{c}$ & $4,36 \mathrm{ab}$ & $4,11 \mathrm{ab}$ & $3,69 \mathrm{a}$ \\
V 2 = Tombatu & $1,88 \mathrm{a}$ & $0,73 \mathrm{a}$ & $4,76 \mathrm{c}$ & $4,75 \mathrm{~b}$ & $4,07 \mathrm{a}$ \\
V 3 = Betavila & $1,74 \mathrm{a}$ & $1,76 \mathrm{ab}$ & $4,34 \mathrm{a}$ & $4,00 \mathrm{a}$ & $3,56 \mathrm{a}$ \\
BNJ 5\% = 13,73 & 2,38 & 1,65 & 0,30 & 0,73 & 2,16 \\
\hline
\end{tabular}

Ket: Angka-angka yang diikuti huruf yang sama menunjukkan tidak berbeda nyata berdasarkan uji BNJ pada taraf $5 \%$

\section{PEMBAHASAN}

\section{Interaksi varietas dan pupuk}

Pengaruh perlakuan interaksi terhadap pertumbuhan dan produksi tanaman tomat (Solanum lycopersicum L.). Berdasarkan hasil analisis ragam menunjukkan bahwa dari 33 variabel pengamatan hanya 4 variabel yang terdapat interaksi nyata antara varietas dengan pupuk bokashi kotoran ayam. Diameter batang tanaman tomat lebih besar pada interaksi varietas Betavila dengan dosis pupuk 15 ton/ha. Ada kesamaan dengan hasil penelitian yang telah dilakukan oleh Dewi dan Jumini (2008) bahwa pupuk organik berpengaruh nyata terhadap diameter batang umur 15 hst dan berpengaruh sangat nyata terhadap diameter batang umur 30 hst. Hal ini membuktikan bahwa pemberian pupuk bokashi kotoran ayam dapat menambah kelansungan unsur hara dalam tanah sehingga dapat diserap oleh tanaman untuk merangsang pertumbuhan secara keseluruhan khususnya batang. Jumlah daun antara varietas Tantyna dan Tombatu lebih besar pada interaksi varietas Tantyna dan dosis pupuk bokashi 10 ton perha. Hal ini sesuai dengan penelitian yang dilakukan oleh Luthfyrakhman dan Susilo (2013), bahwa pupuk kandang ayam memberikan pengaruh yang nyata terhadap jumlah daun pada umur 2 MST, 4 MST, dan 8 MST serta tidak berpengaruh nyata pada umur 6 MST. Makin tinggi nitrogen yang tersedia bagi tanaman maka makin banyak pula pertumbuhan batang, tunas dan daun pada tanaman. Nitrogen merupakan penyusun dari banyak senyawa seperti asam amino yang diperlukan dalam pembentukan atau pertumbuhan bagian-bagian vegetatif seperti batang, daun, dan akar. Jumlah cabang produksi antara varietas Betavila dan varietas Tombatu lebih besar pada dosis pupuk 10 ton/ha.

Hal ini sesuai dengan hasil penelitian Tirtajaya dkk, (2012) menunjukkan pemberian dosis pupuk kandang ayam 125\% dan NPK 50\% memberikan hasil tertinggi untuk jumlah daun, jumlah cabang, dan jumlah tandan bunga tanaman tomat; dosis pupuk kandang ayam $125 \%$ dan NPK $100 \%$ memberikan hasil tertinggi untuk jumlah buah dan total bobot buah; dosis pupuk kandang ayam $100 \%$ dan NPK $50 \%$ memberikan hasil tertinggi untuk tinggi tanaman; dosis pupuk kandang ayam $100 \%$ dan NPK $25 \%$ memberikan hasil tertinggi untuk diameter buah; dosis pupuk kandang ayam 100\% dan NPK 100\% memberikan hasil tertinggi untuk bobot per buah. Diduga nitrogen sudah dapat digunakan secara optimal oleh tanaman untuk pembentukan cabang. Pemanjangan cabang dan memacu perkembangan pertumbuhan tanaman dipengaruhi oleh beberapa faktor, salah satunya adalah air dan mineral. Percabangan sangat tergantung pada faktor yang menguntungkan pertumbuhan vegetatif yang cepat. Nitrogen yang cukup mempunyai pengaruh dominan pada percabangan. Jumlah tandan buah antara varietas Tantyna dan varietas Betavila lebih besar pada perlakuan interaksi varietas Tantyna dan dosis pupuk 10 ton/ha. Pupuk bokashi kotoran ayam selain dapat memperbaiki kesuburan tanah juga merupakan sumber bahan organik di dalam tanah. Bahan organik selain merupakan sumber unsur hara tanah juga mampu meningkatkan kemampuan tanah dalam mempertukarkan kation, sehingga ketersediaan hara dalam tanah meningkat. Tandan buah dan jumlah buah memiliki hubungan yang sangat erat. Hasil penelitian tomat hibrida oleh Luthfyrakhman dan Susilo (2013) menunjukkan bahwa pemberian 
pupuk bokashi kotoran ayam dapat meningkatkan bobot dan jumlah buah. Pupuk bokashi kotoran ayam mengandung selain $\mathrm{N}, \mathrm{P}$ dan $\mathrm{K}$, juga $\mathrm{Mg}$, $\mathrm{S}, \mathrm{Ca}$ dan unsur hara mikro yang masing-masing berfungsi pada proses fisiologi tanaman. Selanjutnya dari 33 variabel pengamatan terdapat 29 vaeiabel yang memiliki perlakuan interaksi varietas dengan pupuk bokashi kotoran ayam tidak berpengaruh nyata. Hal ini diduga bahwa masing-masing dari varietas dan pupuk bokashi kotoran ayam tidak saling berinteraksi. Namun terjadi variasi pertambahan jumlah pada parameter tersebut di setiap umur pengamatan, sehingga didapati pertumbuhan dan produksi tanaman tomat terbaik di jumpai pada perlakuan interaksi varietas Betavila dengan dosis pupuk bokashi kotoran ayam 15 ton per ha.

\section{Pengaruh Varietas}

Pengaruh perlakuan varietas terhadap pertumbuhan dan produksi tanaman tomat

(Solanum lycopersicum L.). Berdasarkan hasil penelitian dari ke 33 variabel pada setiap umur tanaman yang diamati perlakuan varietas berpengaruh nyata hanya pada 21 variabel yang diamati, dan didapati bahwa pertumbuhan dan produksi tanaman tomat terbaik di peroleh pada perlakuan varietas Betavila. Hal ini di dukung oleh hasil penelitian Dewi dan Jumini (2008) bahwa Varietas berpengaruh nyata terhadap diameter batang tanaman tomat pada umur 30 dan 45 hst. Meningkatnya pertumbuhan dan produksi tanaman tomat pada varietas Betavila diduga karena varietas tersebut mampu beradaptasi dengan baik terhadap kondisi lingkungan tempat tumbuhnya sehingga dapat menunjukkan respons yang baik terhadap pertumbuhan tanaman dan meningkatnya jumlah buah/tanaman. Tingginya produksi suatu varietas dikarenakan varietas tersebut mampu beradaptasi dengan lingkungan hidupnya. Penggunaan benih unggul dan cara bercocok tanam yang tepat dapat mempengaruhi produksi yang akan dicapai baik secara kuantitas maupun kualitas. Selain itu juga produksi tomat sangat dipengaruhi oleh adaptasi tanaman tersebut terhadap daerah dataran tinggi dan dataran rendah. Hasil penelitian Abiddin dkk (2013) menunjukkan bahwa tanaman tomat varietas Rempai merupakan varietas yang paling baik pertumbuhannya dan menghasilkan produksi yang optimal dibandingkan dengan varietas Vida dan Super king. Dosis pupuk kandang yang optimum untuk meningkatkan pertumbuhan dan produksi tanaman tomat terdapat pada perlakuan P2 (500 gram/polybag). Interaksi antara varietas tomat dataran rendah dan dosis pupuk kandang dapat memberikan respons yang positif terhadap pertumbuhan dan produksi tanaman tomat.

Varietas Betavila merupakan salah satu jenis varietas unggul yang memiliki kelebihan dari varietas lokal. Pada varietas ini diameter batang yang lebih besar, jumlah bunga, jumlah cabang produksi, jumlah tandan buah, jumlah buah pertanaman lebih banyak dibandingkan dengan varietas Tantyna. dan varietas Tombatu. Sifat genetik mempengaruhi dalam pertumbuhan dan perkembangan tanaman. Hal ini sesuai dengan pernyataan Gardner et al, (1991) menyatakan bahwa faktor internal perangsang pertumbuhan tanaman ada dalam kendali genetik, tetapi unsurunsur iklim, tanah, dan biologi seperti hama, penyakit, gulma, serta persaingan dalam mendapatkan unsur hara yang dapat mempengaruhi pertumbuhan dan hasilnya. Menurut (Sadjad, 1993) perbedaan daya tumbuh antara varietas yang berbeda ditentukan oleh faktor genetiknya. Selanjutnya (Ginting, 1991) menambahkan bahwa tanaman yang berbeda varietas mempunyai pertumbuhan yang berbeda walaupun ditanam pada tanah yang sama.

\section{Pengaruh pupuk bokashi kotoran ayam}

Pengaruh perlakuan dosis pupuk bokashi kotoran ayam terhadap pertumbuhan dan produksi tanaman tomat (Solanum lycopersicum L.). Dari ke 33 variabel pada setiap umur tanaman yang diamati hannya 4 variabel yang terdapat pengaruh nyata. Dari empat taraf dosis pupuk bokashi kotoran ayam yang dicobakan maka ada kecenderungan potensi pada dosis pupuk bokashi kotoran ayam pada pertumbuhan dan produksi tanaman tomat. Selanjutnya dari empat perlakuan dosis pupuk bokasi kotoran ayam maka terdapat pertumbuhan yang lebih baik yang di jumpai pada dosis pupuk bokashi kotoran ayam 15 ton/ha. Hal tersebut mungkin disebabkan pada pemenuhan unsur $\mathrm{N}$ oleh pupuk kandang ayam. Hasil penelitian Pangaribuan dan Hidayat Pujisiswanto (2008) menunjukkan bahwa aplikasi pupuk bokashi kotoran ayam mampu meningkatkan konsentrasi hara dalam tanah, terutama N, P dan $\mathrm{K}$ serta unsur hara lainnya. Selain itu pupuk bokashi kotoran ayam dapat memperbaiki tata udara tanah dan air tanah, dengan demikian 
perakaran tanaman akan berkembang dengan baik dan akar dapat menyerap unsur hara yang lebih banyak terutama unsur hara $\mathrm{N}$ yang akan meningkatkan pertumbuhan dan produksi tomat.

Pupuk bokashi kotoran ayam yang dicobakan dalam penelitian ini mampu memperbaiki kondisi kesuburan tanah untuk menciptakan kondisi fisik, kimia dan biologi tanah untuk mendukung pertumbuhan dan perkembangan tanaman, sehingga memungkinkan ketersediaan air, oksigen dan unsur hara dalam jumlah yang cukup untuk pertumbuhan tanaman. Hasil penelitian (Pangaribuan dkk, 2012) menunjukkan bahwa pupuk bokashi kandang ayam yang dikombinasikan dengan setengah dosis pupuk rekomendasi dapat meningkatkan hasil tomat dibandingkan dengan bokashi pupuk kandang kambing, sapi dan kuda. Bokashi berbasis kotoran ternak seperti kotoran ayam, sapi, kambing dan kuda yang dikombinasikan dengan pupuk anorganik setengah dosis anjuran dapat diterapkan guna penghematan penggunaan pupuk anorganik pada budidaya tomat. Bokashi kotoran ayam adalah bokashi yang terbaik diantara semua jenis bokashi kotoran ternak. Secara umum bokashi pupuk kandang ayam mengandung unsur hara $4,96 \%, \mathrm{P}_{2} \mathrm{O}_{5} 0,34 \%, \mathrm{~K}_{2} \mathrm{O}$ $1,90 \%$, protein $30,20 \%$, karbohidrat $22,96 \%$, lemak $11,21 \%$, alkohol $114,03 \% \mathrm{mg} / 100 \mathrm{~g}$ dan kandungan gula $15,75 \%$ serta vitamin $\mathrm{C} 0,46$ $\mathrm{mg} / 100 \mathrm{~g}$, vitamin $\mathrm{B}_{12} 5,04 \mathrm{mg} / 100 \mathrm{~g}$, asam amino $80,19 \mathrm{mg} / 100$ demikian pernyataan Wididana dan Wigenasentana (1991). Berdasarkan uraian diatas maka bokashi pupuk kandang ayam dapat dijadikan sebagai salah satu sumber bahan organik yang dapat membantu meningkatkan pertumbuhan dan produksi tanaman.

\section{Kesimpulan}

Berdasarkan hasil analisis dan pembahasan pada penelitian ini, maka dapat diambil beberapa kesimpulan sebagai berikut:

1) Pertumbuhan dan produksi tanaman tomat terbaik terdapat pada perlakuan interaksi antara varietas Betavila dan dosis pupuk bokashi kotoran ayam 15 ton per ha.

2) Varietas Betavila memberikan pertumbuhan dan hasil yang paling baik dibandingkan varietas Tantyna dan varietas Tombatu.

3) Perlakuan dosis pupuk bokashi kotoran ayam 15 ton/ha adalah yang paling baik untuk pertumbuhan dan hasil tanaman tomat.

\section{DAFTAR PUSTAKA}

Abiddin, A.Z., Kardhinata, E.H. dan Husni, Y. 2013. Respons dan produksi beberapa Varietas tomat (Lycopersicum esculentum L.) dataran rendah terhadap pemberian pupuk kandang ayam. Jurnal Online Agroekoteknologi ISSN No. 2337- 6597 Vol. 2, No.4: 1401-1407, September214.http:// jurnal.usu.ac.id/index.php/agroekoteknologi/ article/viewFile/8433/3669 Diakses tanggal 23 Mei 2017.

Cahyono. 2005. Budidaya Tomat dan Analisis UsahaTani.indrabbab.blogspot.com/2011/06/ vbehaviorurdefaultvmlo.html.Yogyakarta. Diakses tanggal 23 Mei 2017.

Dewi, P. dan Jumini. 2012. Pertumbuhan dan hasil dua varietas tomat akibat perlakuan Jenis pupuk. www.jurnal.usyiah.ac.id/ floratek/ article/521/441. Diakses tanggal 23 Mei 2017.

Direktorat Jendral Hortikultura. 2014. Statistik Produksi Hortikultura Tahun 2014. http://www.hortikultura.pertanian.go.id Diakses tanggal 23 Mei 2017.

Dinas Pertanian, Peternakan dan Perkebunan Kabupaten Minahasa Utara, 2014. Produksi Tanaman Sayur Menurut Kecamatan dan Jenis Sayuran di Kabupaten Minahasa Utara, 2014 - 2015. https://minutkab.bps.go.id/ frontend/linkTabelStatis/view/id/27. Diakses tanggal 24 Mei 2017.

Firmanto, B.H. 2011. Sukses Bertanam Tomat Secara Organik. Angkasa. Bandung.

Gardner, F.P., R.B. Peace dan R.L. Mitchell. 1991. Fisiologi Tanaman Budidaya (Edisi Terjemahan oleh Herawati, Susilo dan Subiyanto). Universitas Indonesia Press. Jakarta.epository.ipb.ac.id/jspui/bitstream/12 3456789/52846/9/Daftar\%20Pustaka.pdfoleh WM Ningrum - 2011Physiology of Crop Plants. (diterjemahkan dari: Fisiologi Tanaman Budidaya, penerjemah: Herawati. Susilo). Penerbit Universitas Indonesia. Jakarta. 
Ginting, M. 1991. Pengujian Pupuk Komplesal dan Hasil Tanaman Kedelai (Glicine max (L.) Merril). Skripsi. Fakultas Pertanian Universitas Syiah Kuala. Darussalam-Banda Aceh.

Hartatik dan Widowati, 2006. Pupuk Kandang, hal 59-82. Dalam R. D. M.

Simanungkalit, D. A. Suriadikarta, R. Saraswati, D. Setyorini, dan W.

Hartatik (Eds). Pupuk Kandang. Pupuk Organik dan Pupuk Hayati (Organic Fertilizer and Biofertilizer). Balai Besar Litbang Sumberdaya Lahan Pertanian Badan Penelitian dan pengembangan pertanian, Bogor.

Hasibuan,B.E.2004.PupukdanPemupukan.reposit ory.umy.ac.id/bitstream/handle/123456789/.. IDAFTAR\%20PUSTAKA. pdf?.......Fakultas Pertanian Universitas Sumatra Utara - Press, Medan. Diakses tanggal 24 juli 2017.

Laboratorium tanah Fakultas Pertanian Universitas Sam Ratulangi Manado Di laksanakan tanggal 7 Oktober 2017.

Luthfyrakhman, H dan A. D. Susila, 2013. Optimasi Dosis pupuk Anorganik dan pupuk kandang ayam pada budidaya tomat Hibrida.download.portalgaruda.org/article.p $h p ?$ article $=5292 \& \mathrm{val}=197$ Bull. Agrohorti 1 (1):119 - 126. Diakses tanggal 24 Mei 2017

Martin, 2006. Effects of Fresh and Composted Dairy Manure Aplications on Alfafa Yield and the Environment. Agron. J. No.98: $80-$ 84.
Munawar, 2011. Kesuburan Tanah dan Nutrisi Tanaman. IPB Press, Bogor.

Pangaribuan, D. dan Hidayat Pujisiswanto. 2008. Pengaruh Dosis Kompos Pupuk Kandang Sapi terhadap Pertumbuhan dan Produksi Buah Tomat. Prosiding Seminar Nasional Sains dan Teknologi-II. 2008. Universitas Lampung Pangaribuan, D. H., M. Yasir, dan N. K. Utami, 2012. Dampak Bokashi kotoran ternak dalam pengurangan pemakaian pupuk Anorganik pada budidaya tanaman tomat.J.Agron Indonesia 40 (3):204 - 210: Bandar Lampung. Diakses tanggal 12 juni 2017.

Sudiro, A, 2011. Demontrasi Teknologi Pembuatan pupuk organik Cair dari Urine sapi di Kabupaten Sinjai. www.sulsel. litbang.deptan.go.id, diakses tanggal 2 Oktober 2017.

Tirtajaya Nosa Pradana, Elfarisna dan Rosdiana. 2013. Respon pertumbuhan dan produksi tanaman tomat (Lycopersicon esculentum Miil) terhadap dosis pupuk kandang ayam dandosispupukNPK.repository.ut.ac.id/26 10/1/fmipa2013_d2nosaelfarisnarosdiana .pdf. Diakses tanggal 2 Oktoner 2017.

Wididana G.N. dan Wigenasentana, 1991. Applicarion of Effective Microorganisms (EM) and Bokashi on Nature Farming. National University. Jakarta.

Wigati, Syukur dan Bambang. 2006. Pengaruh Takaran Bahan Organik dan Tingkat Kelengasan Tanah Terhadap Serapan Fosfor oleh Kacang Tunggak di Tanah Pasir Pantai. J.K Ling. 